\title{
From ethnic to legal and economic separatism
}

\section{Federalism and the 'parade of sovereignties'}

With a population of 145 million citizens the Russian Federation is one of the most populous and ethnically diverse states in the world. Within its vast territory, which encompasses one-eighth of the world's land surface, reside 128 officially recognised nations and ethnic groups. ${ }^{1}$ As we discussed in chapter 2 , of the 89 republics and regions that make up the Russian Federation, 32 are based on ethnic criteria; namely, 21 republics, 10 autonomous okrugs and 1 autonomous oblast. In such large multinational states, federalism, it is argued, can be a positive or a negative phenomenon.

For those who stress the positive side, federalism functions as a form of empowerment for regional groups and protects minorities from the tyranny of the majority. According to Watts, federalism refers to the advocacy of multi-tiered government combining elements of shared rule and regional self-rule. 'It is based on the presumed values of achieving both unity and diversity by accommodating, preserving and promoting distinct identities within a larger political union'.2

As Kempton notes, federalism 'allows many minority groups to sustain themselves by making them the majority within a specific component of the larger state' ${ }^{3}$ Most importantly of all, by providing a democratic alternative to nation-statehood, federalism provides a viable alternative to regional secession and the potential disintegration of multinational states. In this regard it has been successful in quelling ethnic and religious tensions in Canada, Belgium, India, Malaysia, Nigeria, Spain and South Africa. ${ }^{4}$

For those who stress the negative side, federalism is the problem rather than the solution, particularly in multinational states where ethnic boundaries coincide with boundaries of the federal subjects. Federalism, according to this scenario, is much more likely to intensify the nationalist grievances it is supposed to ameliorate. As Smith notes: 
Federalism provides incentives for structuring group/class conflicts along territorial lines, [and] when the territories in question are spatial surrogates of large-scale, potentially self-conscious cultural communities, most territorial conflicts become community conflicts as well. In the process, feelings of ethnicity are strengthened and new issues take on ethno-territorial significance. $^{5}$

Federalism can also lead to the creation of new national communities, as was the case in the USSR. By granting ethnic communities virtually all of the trappings of statehood (constitutions, flags, hymns, parliaments, executive bodies, courts etc.), federalism, it is argued, simply provides such communities with the institutional and cultural building blocks to go one step further and forge separate states. In other words, the drawing of regional boundaries intrinsic to federalism acts to reify and reproduce the very group differences to which federalism is itself a response.

However, it is doubtful that the Russian state would still exist today in its current form if it were not for the federal arrangements codified in the 1992 Federal Treaty, the 1993 Constitution and the numerous bilateral treaties which were negotiated over the period 1992-98. These federal arrangements helped to quell nationalism in the republics and eventually brought an end to the 'parade of sovereignties' which dominated the political landscape in the early 1990s.

With the exception of the wars in Chechnya, and sporadic inter-ethnic conflicts and tensions in the Caucasus, even Russia's weak and imperfect form of federalism has succeeded in quelling outright demands for separation. Bilateral deals struck between the centre and the republics transformed the regions zero-sum demands for secession into more negotiable and viable demands for greater legal, economic and political sovereignty.

No doubt, Yeltsin's dissolution of the Russian parliament and the horrific events of the 'October days' in 1993, coupled with the sending of federal troops into secessionist Chechnya in 1994 and 1999, has also helped to persuade ethnic groups to change tactics and to opt for negotiation rather than conflict. ${ }^{6}$ The rise of Russian nationalism and the calls from nationalists for the liquidation of the ethnically based federal subjects, and the 'gubernisation of Russia' may also have convinced regional elites of the need to find some urgent form of accommodation with the Yeltsin regime.

Payin argues rightly that the bilateral treaties between Moscow and the republics 'severely weakened the positions of radical nationalist forces, whose influence was based almost entirely on notions of an imperial enemy'. ${ }^{7}$ Thus, for example, the radical nationalist movement in Tatarstan, which had been fairly strong, literally fell apart after the signing of the treaty between Moscow and Kazan in 1994. ${ }^{8}$ And nationalist movements in other republics have so far, failed to gain support at the ballot box. ${ }^{9}$

However, Yeltsin's compromise with the ethnic republics was bought 
at a cost - at the cost of undermining the Federal Constitution and the sanctioning of authoritarianism. ${ }^{10}$ As Furman notes: 'The federal centre agreed to grant the republics more rights than the Russian provinces, allowing them to develop into 'vassal kingdoms' in whose internal affairs Moscow did not interfere as long as they regularly paid Yeltsin their 'tribute' in the form of votes - which they did in every important federal election' ${ }^{11}$ We discuss these ideas further in chapter 9.

\section{Federalism and secessionism}

The outright disintegration of the Russian Federation remains highly unlikely given the ethnic makeup and geo-political status of Russia's thirty-two ethnically defined subjects. The following six demographic, geo-political and social factors have conspired to weaken or stifle the development of separatist movements. (1) Nationality based entities (including autonomous regions) occupy 53 per cent of the country's area, but only 18 per cent of the population lives in those regions. ${ }^{12}$ (2) Furthermore, according to a micro-census carried out in 1994 Russians now make up the overwhelming majority of the population (82.95 per cent), compared to 50 per cent in the USSR. ${ }^{13}$ (3) Of the 172 ethnic groups the largest, the Tatars, make up only 3.8 per cent of the population (followed by the Ukrainians (2.3), Chuvash with (1.2), Bashkirs (0.9), Belarussians (0.7) and Mordvinians (0.6): all the other ethnic groups comprise less than 1 per cent. ${ }^{14}$ (4) Russians predominate not only in the Russian Federation as a whole but also in most of its regions - in 74 of the 89 members of the Federation. Indeed, forty-nine regions can be called purely Russian areas. In those regions, representatives of the ethnic majority make up 85 to 98 per cent of the population. The largest per centage of Russians in any region is now found in Tambov oblast (97.8 per cent). ${ }^{15}$ (5) The ethnic republics make up just 28.6 per cent of the territory and only 15.7 per cent of the population. ${ }^{16}$ Furthermore, of the twenty-one republics, the eponymous population comprises a majority in only seven; Chechnya, Chuvashiya, Dagestan, ${ }^{17}$ Ingushetiya, Kalmykiya, North Osetiya-Alaniya, and Tyva, and a plurality in two, Kabardino-Balkariya and Tatarstan. Russians, on the other hand, have an absolute majority in nine, Adygeya, Buryatiya, Altai, Kareliya, Khakassiya, Komi, Mordoviya, Sakha (Yakutiya) and Udmurtiya; and a plurality in three, Bashkortostan, Karachai-Cherkessiya and Marii-El (see table 4.1). (6) Finally, of the eleven autonomous areas (the ten autonomous okrugs (AOs) and the autonomous oblast (AOB)) the eponymous population comprises a majority in only two, Aga-Buryatiya AO and Komi-Permyakiya AO (see table 4.2).

However, we should caution that the numbers of eponymous peoples are rising in their native regions where the rates of population growth are 
Table 4.1 Ethnic composition of the republics, 1989 (\%)

\begin{tabular}{lcc}
\hline Republic & Eponymous population(s) & Russian population \\
\hline Adygeya & 22.1 & 68.0 \\
Altai & 31.2 & 60.4 \\
Bashkortostan & 21.9 & 39.3 \\
Buryatiya & 24.0 & 70.0 \\
Chechnya-Ingushetiya & 70.7 & 23.1 \\
Chuvashiya & 68.7 & 26.7 \\
Dagestan & 90.8 & 9.2 \\
Kabardino-Balkariya & 57.6 & 32.0 \\
Kalmykiya & 53.0 & 37.7 \\
Karachai-Cherkessiya & 40.9 & 42.4 \\
Kareliya & 10.0 & 73.6 \\
Khakassiya & 11.1 & 79.5 \\
Komi & 23.3 & 57.7 \\
Marii-El & 43.3 & 47.5 \\
Mordoviya & 32.5 & 60.8 \\
North Ossetiya & 53.0 & 29.9 \\
Sakha (Yakutiya) & 33.4 & 50.3 \\
Tatarstan & 48.5 & 43.3 \\
Tyva & 64.3 & 32.0 \\
Udmurtiya & 30.9 & 58.9 \\
\hline
\end{tabular}

Source: G. W. Lapidus and E. W. Walker, Nationalism, regionalism, and federalism: centre-periphery relations in post-communist Russia', in G. W. Lapidus (ed.), The New Russia: Troubled Transition (Boulder, Colorado: Westview Press, 1995), pp. 88-9; E. Payin and A. Susarov, 'Line five in the mirror of demography', Rossiiskie Vesti, October 30, 1997, 2. Translated in CDPSP, 49:44 (1997), 11.

greater for the indigenous population than for the Russian population. We have also witnessed the return migration of representatives of the eponymous nationalities from other parts of Russia, the Baltic states, and the Confederation of Independent states. Whilst at the same time there has been a steady outflow of Russians from a number of regions. Thus, for example, the per centage of Kalmyki in Kalmykiya grew from 41.5 per cent in 1979 to 52.6 per cent in $1994 .^{18}$

One would imagine that demands for secession are likely to be strongest in those republics: (1) situated in the outer rim of the Federation which border on foreign states; and (2) where a majority of the population is eponymous. ${ }^{19}$ Of the seven republics where the eponymous population comprises a majority, Chuvashiya is an enclave with no realistic prospects for secession. This leaves only six republics where there is a majority of the eponymous population and the subjects are situated on the outer rim of the Russian state: Chechnya, Dagestan, Ingushetiya, 
Table 4.2 Ethnic composition of the autonomous areas, 1989 (\%)

\begin{tabular}{lcc}
\hline Autonomous areas & Eponymous population(s) & Russian population \\
\hline Autonomous oblast (1) & 4.2 & \\
Jewish & & 83.2 \\
Autonomous okrugs (10) & 54.9 & 40.8 \\
Agin-Buryat & 7.3 & 66.1 \\
Chukotka & 14.0 & 67.5 \\
Yevenk & 60.2 & 36.1 \\
Komi-Permyak & 16.5 & 62.0 \\
Koryakiya & 0.9 & 66.3 \\
Khanty-Mansi & 11.9 & 65.8 \\
Nenets & 13.7 & 67.1 \\
Taimyr & 36.3 & 56.5 \\
Ust'-Ordin Buryat & 4.2 & 59.2 \\
Yamala-Nenets & & \\
\hline
\end{tabular}

Source: Lapidus and Walker, The New Russia, p. 89.

Kalmykiya, North Osetiya-Alaniya and Tyva. ${ }^{20}$ And indeed it is these republics, mainly to be found in the North Caucuses which have proven to be the most vociferous in their demands for autonomy. But only Chechnya has opted for secession and it has had to pay the price of two wars, the loss of thousands of its citizens, occupation by Russian troops, and the imposition of a pro-Moscow 'puppet government'. Of the other five republics, as Payin notes, North Osetiya-Alaniya can be excluded, for, 'as the only Christian autonomy in the Muslim North Caucasus, it will not want to leave Russia under any readily conceivable circumstances' ${ }^{21}$ Secession from the Federation is also highly unlikely in the multi-ethnic state of Dagestan, since the majority of the population realise that even the suggestion of secession from Russia would invite an explosion of demands for internal secession and of internal conflicts amongst it thirtythree ethnic groups. ${ }^{22}$

Another factor which has dampened down calls for independence from these states is their dire economic situation and financial dependence on the centre. Thus, for example, although we may expect nationalism to be strong in Tyva, which was nominally a sovereign state from 1921 to 1944, demands for secession have been stifled by the fact, that the Republic depends on the federal authorities for 90 per cent of its income. And Dagestan, Ingushetiya, Kalmykiya, and North Osetiya-Alaniya are also highly dependent on federal subsidies (see chapter 5).

It is interesting also in this respect to consider the point that the eponymous population in three of the most radical and confederalist republics, Bashkortostan, Sakha (Yakutiya) and Tatarstan, make up only 21.9 
per cent, 33.4 per cent and 48.5 per cent of the population, respectively. Whilst the Russian population comprises a plurality of 39.3 per cent in Bashkortostan, a majority of 50.3 per cent in Sakha (Yakutiya), and a sizeable minority of 43.3 per cent in Tatarstan. And of course all three of these republics are like Chuvashiya, landlocked inside Russia with no realistic prospects for separation.

In Bashkortostan, Bashkirs are the third largest ethnic group in the Republic, some way behind Tatars, and Russians. However, in an attempt to gain an external foreign border, Bashkortostan has recently begun negotiations for an exchange of territory with the neighbouring region of Orenburg. If successful this would allow Bashkortostan to establish a direct border connection with Kazakhstan which is only fifty kilometres away. The area in question has a high per centage of Tatar and Bashkir populations. ${ }^{23}$

Other sources of ethnic tension can be found in the republics of Kabardino-Balkariya and Karachaevo-Cherkessiya. Here the question is not one of secession from Russia but, rather, calls for the division of each of these republics into two new entities providing separate homelands for the Kabards, Balkars, Karachais and Cherkess. In other regions there have been calls for unification rather than separation. Thus, for example, there has been strong support from citizens in Bashkortostan and Tatarstan for the idea of creating closer economic and political ties in some kind of confederacy. ${ }^{24}$

\section{The autonomous formations}

The ten autonomous okrugs (AOs) which are considered by the constitution to be full subjects of the federation, are in fact trapped 'matroshka doll-like', within the territories of eight other federal subjects. The AginBuryat AO within Chita Oblast; Chukotka (Magadan Oblast); Yevenk and Taimyr AOs (Krasnoyarsk Krai); Khanty-Mansi and Yamala-Nenets (Tyumen Oblast); Komi-Permyak (Perm Oblast); Koryakiya (Kamchatka oblast); Nenets (Arkhangelskaya Oblast); Ust'-Orda Buryat (Irkutsk Oblast).

The Constitution is rather unclear as to what their proper relationship should be with the regional authorities in whose territories they are situated. Their legal status is contradictory. On the one hand they are administratively subordinate to the regions of which they are part but on the other hand they are also constitutionally equal to them. In an attempt to solve this anomalous situation, the Constitution states that relations between the okrugs and the regions should be 'treaty based'. In 1997 the Russian Federation Constitutional Court ruled that where conflict arises and there is no treaty (as was the case in Tyumen oblast in 1997) then the autonomous okrug is equal in status to the region. ${ }^{25}$ By this ruling the 
regional authorities are not allowed to interfere in the administration of the okrugs, but on the other hand, the populations of the okrugs are allowed to participate in the elections of their 'parent regions'. Such an interpretation actually appears to makes the autonomous okrugs 'more equal' than the regions in which they are situated. ${ }^{26}$

The special status of the autonomies becomes more questionable when we consider their ethnic makeup (see table 4.2). In only two of the eleven (Aga-Buryatiya and Komi-Permyakiya) does the eponymous population comprise a majority, whilst in the remaining nine the Russian population predominates. And in a number of the autonomous okrugs the per centage of the indigenous population is tiny. Why it may be asked are Khanty-Mansi and Yamalo-Nenets okrugs (with indigenous populations of just 0.9 and 4.2 per cent respectively) granted full membership of the federation, with the right (until January 2002, see chapter 8) to send two representatives to the upper chamber of the parliament, and to maintain their own charters and other trappings of statehood ${ }^{27}$ As we shall discuss below, these questions become all the more critical when they involve disputes over who should control the economic spoils of the okrugs - the okrugs, or their 'parent regions'.

Recently we have witnessed the situation of autonomous okrugs demanding independence from their 'parent' regions (e.g., Khanty-Mansi and Yamalo-Nenets from Tyumen Oblast) and paradoxically others seeking to be fully integrated into their parent oblasts (e.g., KomiPermyak Okrug with Perm Oblast). As Paretskaya rightly stresses, the main reasons for both kinds of change of status are economic. Perm Oblast is happy to be free of the social responsibility of its impoverished okrug. By contrast, Khanty-Mansi and Yamalo-Nenents okrugs are fabulously wealthy oil and gas producers. By seceding from Tyumen Oblast the okrugs will no longer have to give up a per centage of their oil and gas revenues to the Oblast authorities. The majority of citizens in both okrugs boycotted the 1997 gubernatorial election in Tyumen Oblast. ${ }^{28}$ Failing in their quest for seccession these two okrugs have recently adopted a new strategy - to take control of the Oblast's economy. As Arbatskaya notes: 'Effectively, the okrugs, and especially Khanty-Mansi, are buying up the largest tax-paying enterprises in the south. Over time these purchases will give the northern okrugs control of the political processes in the region, particularly local elections and elections to the oblast Duma'. ${ }^{29}$

A similar battle has been raging between the leaderships of Krasnoyarsk Krai and the Taimyr autonomous okrug over the profits of the Norilsk Nickel Factory which supplies 20 per cent of the world's nickel and 5 per cent of its copper. The factory provides some 70 per cent of the krai's income. The battle began when in collusion with its director, the Taimyr authorities unilaterally transferred the factory from the krai to 
their jurisdiction. Such a move guaranteed that the spoils of the factory would no longer go to the krai but would instead flow into the coffers of the okrug. The factory would also benefit from the move, as it would gain access to Taimyr's mineral resources and at the same time escape supervision from the krai administration. Tax evasion and corruption were also at the heart of the deal. These actions of the okrug were opposed by the mayor of Norilsk, where the factory was situated. However, after months of wrangling, federal authorities prohibited the transfer of the factory from the krai's jurisdiction. In response the okrug administration boycotted the Krasnoyarsk gubernatorial elections and it declared all laws of the krai invalid in the territory of the okrug. Finally, after years of stalemate and conflict a power sharing agreement was signed in 1997 between the krai and the okrug. The treaty granted the Okrug some of the profits generated by the plant at Norilsk. In a more recent twist to this saga, the former head of Norilsk Nickel, Aleksandr Khloponin was elected governor of Taimyr AO and he has now given his support to a proposal by deputies of the Taimyr legislative assembly to consider the exit of Taimyr from the krai. ${ }^{30}$

Tensions have also arisen over calls by Buryats to unite Russia's two Buryat okrugs with the Republic of Buryatiya to create a 'greater Buryatiya' republic. The Ust-Orda AO which is situated in Irkutsk Oblast and the Agin Buryat AO situated in Chita oblast have historical links with the Republic of Buryatiya, which lies between the two okrugs. ${ }^{31}$

New legislation is being prepared in the presidential administration to bring an end to these anomalies. The solution being suggested is simply to dissolve the okrugs and to amalgamate them with their parent regions. But for the centre to do this unilaterally would mean violating the Constitution which has strict rules for changing the borders of federal subjects. ${ }^{32}$

\section{From ethnic to legal and economic separatism}

For many regions a more realistic option than outright secession has been the development of 'economic' and 'legal' separatism or what Khemkin terms 'internal emigration', the process whereby a number of subjects have withdrawn themselves from the legal and economic orbit of the federation and become de facto autonomous islands within the Russian state. ${ }^{33}$ Thus, as we noted in chapter 3, the constitutions of 19 of Russia's 21 republics (all except Kalmykiya and Kareliya) violate the Federal Constitution. ${ }^{34}$ According to an analysis by the Ministry of Justice, of the 44,000 regional acts adopted over the period 1995-97 almost half were in violation of the Russian Constitution and federal legislation. ${ }^{35}$ And regions and republics regularly pass legislation that infringe citizens' rights. Thus, for example, according to Voronezh Oblast Procurator, 
Aleksandr Frolov, 399 regional directives of the oblast Duma which were adopted in 1998 violated human rights. ${ }^{36}$

What we appeared to be witnessing during the early part of the Yeltsin regime was a 'war of laws' between the federal authorities and the regions reminiscent of the struggle which existed between the Union Republics and the federal authorities during the Gorbachev period.

The ability of the regions to opt for legal separatism has been increased by the fact that the top executive and legislative bodies are now elected from below rather than appointed from above. Up until the gubernatorial elections of 1995-97 the majority of regional chief executives were appointed to their posts by the president. The fact that regional leaders now come to office through the ballot box has significantly enhanced their local powers. No longer can the Russian President simply appoint loyal supporters to rule the regions. ${ }^{37}$ Elections for regional assemblies have also taken place throughout the country and thousands of new deputies have taken their seats in local assemblies. Regional executive heads and the chairs of regional assemblies have been until very recently exofficio members of the Federation Council and new elections in the regions led to changes in its composition weakening Yeltsin's control over the upper chamber (see chapter 6).

For Lapidus these trends gave rise during the late 1990s to fears, that, at best, Russia [was] being progressively transformed from a federation to a confederation, and at worst that it [would] be thrown backward to the period of medieval chaos and conflict known as the era of 'appanage principalities'. ${ }^{38}$ And Sakwa argues that by the end of the Yeltsin era Russia had witnessed the development of what he calls 'segmented regionalism', a process which 'fragmented the country, juridically, economically and, implicitly, in terms of sovereignty' and which transformed the country from a multinational state into a 'multi-state state' ${ }^{39}$ In a similar vein, Smith speaks of the creation of 'regional states' - regions which have increasingly adopted 'many of the features usually ascribed to the modern nation-state'.$^{40}$ By the mid-1990s major economic and political powers had passed from the centre to the regions and regional politics was firmly under the control of regional elites.

\section{Economic separatism}

Regional elites have also opted for economic separatism. As Smith writes, 'seven decades of centrally directed economic coordination between the regions has given way to the anarchy of regional autarky'. ${ }^{41}$ With the breakdown of the Soviet centrally planned system, and a massive collapse in industrial production, regions have increasingly been forced to turn inward absorbed only by their own selfish interests. One symptom has been the breakdown of inter-regional trade, exacerbated by the dramatic 
fall in regional production. Thus, for example, the share of inter-regional trade as a part of Russia's gross regional product fell from 22 per cent in 1990 to approximately $12-14$ per cent in $2000 .{ }^{42}$

Benefiting from the continuing political stalemate in Moscow a number of republics have refused to implement legislation concerning the privatisation of land, and in some regions (particularly those controlled by the communists) we have witnessed a denationalisation of industry. A number of republics have also unilaterally taken control of their land and natural resources. And throughout the 1990s regions and republics continued to attempt to blackmail the federal authorities by withholding taxes from Moscow. In those regions where privatisation has gone ahead there have been fierce battles between the centre and the regions over who should benefit from the spoils of these programmes.

Federal subjects have also imposed their own import duties and sales taxes on certain goods, prohibited the export of various products from their regions and set their own prices, all in clear violation of article 74 of the Russian Constitution. For example, Omsk Oblast placed a 50 per cent duty on imported alcoholic beverages and a 10 per cent duty on the sale of all imported foods, measures which were expected to bring in additional revenue of 830 billion roubles in 1997. And Yaroslavl' Oblast introduced a 4 per cent sales tax on various goods and services to offset costs for healthcare, education, and child benefits. ${ }^{43}$

These early moves to create regional economic autarkies intensified after the financial crisis of August 1998, when almost every region was forced to adopt protectionist measures to survive. Such actions have continued into the Putin era threatening to turn the Russian economy into a collection of closed regional markets. Putin in his first presidential address to the Duma in July 2000, spoke out against regional protectionism:

The federal authorities are responsible for establishing uniform conditions for economic activity throughout the country. But regional agencies ... are creating barriers to the free circulation of capital, goods and services. This is reprehensible and disgraceful!... Any actions by regional authorities that are aimed at restricting economic freedom must be halted as unconstitutional. ${ }^{44}$

During the Yeltsin period regions were free for the first time in their history to engage in the global economy. A number of republics and regions have now set up diplomatic channels with foreign states and begun to engage in foreign economic activities. Many of the republics now have their own foreign consulates, and they are independent members of international trade organisations. Thus, according to figures published in June 1999 Russian regions had signed more than 1,200 friendship agreements with partners in 69 foreign states. And 'permanent representatives' of the regions had been created in 46 foreign countries. ${ }^{45}$ Over the period 
1991-96, the regions and republics signed more than 300 trade agreements with foreign states and in a number of cases such deals were struck without the participation or sometimes even the knowledge of the relevant ministries in Moscow. Thus, for example, the Ministry of Foreign Affairs expressed some alarm with regard to an agreement signed between Kabardino-Balkariya and the Republic of Abkhazia (Georgia). And in 1995 Moscow was forced to annul a trade treaty between Kaliningrad Oblast and Lithuania as it conflicted with Federal legislation. ${ }^{46}$

\section{The inter-regional economic associations}

In order to increase their leverage with Moscow all of the regions (except Chechnya) have joined one or more of the regional economic associations set up over the period 1992-94 based on Soviet-era geographical administrative divisions. As Klimanov notes: 'In conditions marked by a longterm economic crisis, an undeveloped political system, and the lack of a comprehensive federal system, interregional cooperation expands the internal potential of regions and creates conditions for a more effective resolution of local political and economic problems'. ${ }^{47}$

Box 4.1 lists the eight inter-regional associations, their leaders and membership. As Klimanov notes, in each association there are supraregional institutional structures including an executive and various economic committees. The highest decision making bodies are the councils which usually meet several times a year and are attended by senior government officials, often including the Prime Minister. As a measure of their importance Prime Minister Primakov incorporated the leaders of the associations into his cabinet in $1998 .^{48}$

The associations have played an important role in aggregating and articulating the demands of the regions. As we would expect the most powerful associations are to be found in the most powerful economic regions. In addition to the Siberian lobby, here we may include the associations of the Urals, Volga and Central Russia. ${ }^{49}$

However, the power of the associations to affect policy making at the highest levels has been rather disappointing. The economic interests of the regions that make up each of the associations are highly diverse and regional leaders are often too preoccupied with their own internal problems to mount a unified campaign. Thus, for example, as Klimanov notes, the Siberian agreement is undermined by the division between the regions of west Siberia, whose industries are dominated by military industrial complex, and east Siberia, whose industries are based on the extraction of natural resources.

There are also tensions between regions and ethnic republics, and between those regions which managed to sign bilateral treaties with Moscow and those which did not. As Smith notes: the 'Siberian Accord' 
Box 4.1 The inter-regional associations

1 The Far East and Baikal Association, consists of the republics of Buryatiya and Sakha (Yakutia), Primorskii and Khabarovsk krais, Amur, Kamchatka, Magadan, Chita, and Sakhalin oblasts, the Jewish autonomous oblast, and Koryak and Chukotka autonomous okrugs.

2 The Siberian Accord Association comprises the republics of Buryatiya, Altai, Khakasiya, along with Altai and Kransnoyarsk krais, Irkutsk, Novosibirsk, Omsk, Tomsk, and Kemerovo oblasts, plus Agin-Buryat, Taimyr, Ust-Orda Buryat, Khanty-Mansi, Yevenk, and Yamal-Nenets autonomous okrugs.

3 The Greater Volga Association includes the republics of Tatarstan, Mordoviya, Chuvashiya, and Marii-El, as well as Astrakhan, Volgograd, Nizhnii Novgorod, Penza, Samara, Saratov and Ulyanovsk oblasts.

4 The Central Russia Association is made up of Bryansk, Vladimir, Ivanovo, Kaluga, Kostroma, Moscow, Ryazan, Smolensk, Tver, Tula, and Yaroslavl oblasts, along with the city of Moscow.

5 The Association of Cooperation of Republics, Krais and Oblasts of the Northern Caucuses has on average the lowest standard of living of the eight regional groupings. It includes predominantly agricultural and mountainous areas: the republics of Adygeya, Dagestan, Ingushetiya, Kabardino-Balkariya, Karachaevo-Cherkesiya, North Osetiya-Alaniya, Kalmykiya, Krasnodar and Stavropol Krais and Rostov oblast.

6 The Black Earth Association consists of Voronezh, Belgorod, Kursk, Lipetsk, Orel, and Tambov oblasts.

7 The Urals Regional Association includes the republics of Bashkortostan and Udmurtiya, Komi-Permyak autonomous okrug and Kurgan, Orenburg, Perm, Sverdlovsk and Cheliabinsk oblasts.

8 The North-West Association comprises the republics of Kareliya and Komi, as well as Arkhangelsk, Vologda, Kaliningrad, Kirov, Leningrad, Murmanask, Novgorod, and Pskov oblasts. Nenets Autonomous Okrug, and St Petersburg.

Source: EWI Russian Regional Report, 15 January, 1997.

fragmented 'in part because the larger oblasts resented the way in which Sakha used its position to secure considerable economic and financial autonomy from Moscow'. And Kalmykiya withdrew its membership from the Greater Volga Association after a dispute with neighbouring Astrakhan oblast. ${ }^{50}$ This has allowed the federal leadership to adopt a policy of divide and rule with the associations. Moreover, leaders of the associations tend to use their posts to further the interests of their own regions rather than the associations as a whole and/or as a way of launching national careers. 
Finally, Smirnyagin makes the important point that vertical relations have long dominated horizontal relations in Russia. Horizontal contacts between regions are 'partial and intermittent' and, 'Even when horizontal disputes arise between regions, the leaders of contending regions launch their appeals first to Moscow rather than to each other' ${ }^{51}$ Moreover, as discussed in chapter 8 the powers of the associations have significantly declined since the creation of Putin's seven federal districts in 2000 .

\section{Federalism, ethnicity and democracy}

Local democracy is surely a necessary pre-requisite for democratisation at the national level. And the provision of certain basic democratic procedures should, in a democracy, be universally available to all citizens across the federation regardless of their place of residence. Clearly democracy will be that much more difficult to create and consolidate in multinational states where there are disputes over the boundaries of the state and some groups wish to secede from the federation. Russia's wars with Chechnya have not only frightened other republics into submission, they have also bolstered authoritarianism at the centre and they played a major role in bringing President Putin to power. As Rustow stresses no democracy can be consolidated until consensus has been reached over national unity and any contested boundaries of the state have been settled. ${ }^{52}$ National unity is achieved when the vast majority of citizens in a democracy-to-be ... have no doubt or mental reservations as to which political community they belong to ... [and] the people cannot decide until someone decides who are the people ${ }^{\prime 53}$

A further problem in multinational states, as Smith notes, 'is how to counter domination by either nationalist-minded minorities or the majority national group'. One answer for those who advocate a liberal federation 'is to prioritise the individual rights of citizens regardless of their ethnic or national affiliation'.$^{54}$ For as O'Donnell rightly observes: 'Citizenship can be universally exercised only when the normative system is guided by universal criteria, when the rule of law is effectively enforced, when public powers are willing and able to protect rights, and when all individuals enjoy some social and economic prerequisites' ${ }^{55}$

One of the major failings of the Russian state has been the inability or unwillingness of the federal authorities to give equal rights to its citizens and the centre's tolerance of discrimination against minority nationalities, particularly in the ethnic republics and autonomies. Article 126 of the Russian Constitution guarantees the equality of all citizens regardless of nationality - including political rights. But in Russia republican elites regularly discriminate against minority groups and give preferential political representation to their indigenous populations even when that 
population does not comprise a majority in the given republic. As Kahn notes, whilst republican constitutions are 'replete with declarations about the supremacy of law, open, free and fair multiparty elections, freedom of speech, assembly and conscience', in practice they, 'embed special rights and privileges' for their indigenous citizens. ${ }^{56}$ Thus, for example, most of the constitutions begin with declarations recognising the rights of the multinational peoples of the republics, but conclude 'with the assertion of the right to self-determination of a particular national group' ${ }^{57}$ Thus, article 69 of Bashkortostan's constitution declared that the republic 'was formed as a result of the realisation of the right of the Bashkir nation to self-determination and to defend the interests of all multinational people of the republic', even although as we noted above ethnic Bashkirs make up only 21.9 per cent of the population.

In Adygeya where ethnic Adygeya comprise 22.1 per cent of the population, the Republican Constitution declares that the republic was formed 'as a result of the realisation of the right to self-determination of the Adygeya people and the historically formed community of people who live on its territory' ${ }^{58}$ Non-indigenous citizens of ethnic republics are also discriminated against when it comes to their rights to stand for elected posts (see chapter 9). Thus, for example, ten republics require that candidates, for select political offices, must possess knowledge of both Russian and the titular language. In Sakha, 'where Russians and ethnic Sakha respectively comprise 50.3 per cent and 33.4 per cent of the population, knowledge of both languages is required for candidates for the posts of President and Chairman of either house of the Parliament'. Even although only 2 per cent of Russian's know how to speak Sakha. ${ }^{59}$ In Bashkortostan, where Bashkiri comprise just 22 per cent of the population and where Bashkir is only spoken by 15 per cent of the inhabitants (that is not even by all Bashkiry) the Bashkir language alongside Russian is mandatory for all candidates in presidential elections. ${ }^{60}$ And furthermore this electoral law neglects the languages of the Tatar, Chuvash, Marii and other nationalities which as Khan notes, comprise 36 per cent of the population. ${ }^{61}$

In November 2000 President Aslan Dzharimov of Adygeya made changes to the way the electoral districts were formed in the republic in a blatant attempt to guarantee that a majority of ethnic Adygeys would gain election to the newly created upper chamber of the Republican Parliament, even although, as noted above, Adygeys make up only onequarter of the population of the republic. In defiance of rulings by the Russian Constitutional Court and the Adygeyan prosecutors' office, which declared the elections illegal, Dzharimov pressed ahead with the elections in March 2001. As planned, ethnic Adygeys won a majority of seats. ${ }^{62}$ 
The discrimination against non-indigenous groups in the republics even when these groups comprise a larger per centage of the population than the titular nationality is graphically illustrated by their underrepresentation in government and parliamentary posts. Thus, for example, in the republic of Sakha (Yakutiya), Sakha make up 34 per cent of the population but 69 per cent of posts in government structures. In Tatarstan 78.1 of the governing elite are Tatar even although they comprise 48.3 per cent of the population. And Tatars make up 73.3 per cent of the members of the Tatarstan Parliament - Russians 25.1 per cent and other nationalities 1.6 per cent. $^{63}$

In Buryatiya the Buryats comprise 24.0 per cent of the population but they held 43.1 per cent of the seats in the Republican parliament in June 1994. ${ }^{64}$ Of the eight top politicians in Bashkortostan in 1997 (President, Prime Minister, Head of Presidential Administration, State Secretary, leaders of the State Assembly), seven were Bashkirs in 1997, and only one was Russian. ${ }^{65}$ It is also instructive to note that the per centage of Bashkiry in the republic's elite structures has risen in the post-communist period (see tables 4.3 and 4.4).

However, factors other than the ethnic one must be considered in assessing the likelihood of secession and the prospects for democratic consolidation in the republics. The most important additional factor is the overall wealth and economic status of the federal subjects and the degree to which they are economically dependent on the centre and this is one of the topics we now turn to in chapter 5 .

Table 4.3 Ethnic composition of government elite in Bashkortostan, 1990-97

\begin{tabular}{|c|c|c|c|c|c|c|}
\hline Nationality & $\begin{array}{c}\% \text { of } \\
\text { population }\end{array}$ & $\begin{array}{c}\text { Secretaries } \\
\text { of raikoms } \\
\text { and } \\
\text { gorkoms, } \\
1990\end{array}$ & $\begin{array}{l}\text { Chairs } \\
\text { of raion } \\
\text { and city } \\
\text { soviets, } \\
1990\end{array}$ & $\begin{array}{c}\text { Chairs of } \\
\text { executive } \\
\text { committees } \\
\text { of city } \\
\text { and raion } \\
\text { soviets, } \\
1990\end{array}$ & $\begin{array}{c}\text { Chief } \\
\text { administrators, } \\
\text { cities and } \\
\text { districts, } \\
1997\end{array}$ & $\begin{array}{c}\text { Members } \\
\text { of cabinet } \\
\text { of } \\
\text { ministers, } \\
1997\end{array}$ \\
\hline Bashkir & 21.9 & 44.8 & 44.7 & 32.9 & 58.5 & 65.5 \\
\hline Russian & 39.3 & 31.3 & 32.9 & 21.1 & 15.0 & 19.0 \\
\hline Tatar & 28.4 & 19.4 & 15.8 & 38.2 & 18.5 & 13.0 \\
\hline Others & 10.6 & 4.5 & 6.8 & 7.8 & 8.0 & 2.5 \\
\hline
\end{tabular}

Source: R. Gallyamov, ‘Politicheskie elity Rossiiskikh respublik: osobennosti transformatsii v postsovetskii period', in A. Mel'vil' (ed.), Transformatsiya Rossiiskikh regional'nykh elit $v$ sravnitel'noi perspektive (Moscow: MONF, 1999), p. 167. 
Table 4.4 Ethnic representation of parliamentary elite, 1980-95

\begin{tabular}{lccccc}
\hline Nationality & $\begin{array}{c}\text { Supreme } \\
\text { Soviet, } \\
1980\end{array}$ & $\begin{array}{c}\text { Supreme } \\
\text { Soviet, } \\
1985\end{array}$ & $\begin{array}{c}\text { Supreme } \\
\text { Soviet, } \\
1990\end{array}$ & $\begin{array}{c}\text { State assembly: } \\
\text { chamber of } \\
\text { representatives, } \\
1995\end{array}$ & $\begin{array}{c}\text { State assembly: } \\
\text { legislative } \\
\text { chamber, } \\
1995\end{array}$ \\
\hline Bashkir & 38.6 & 40.3 & 33.5 & 41.1 & 55.8 \\
Russian & 33.2 & 32.8 & 35.7 & 23.3 & 20.5 \\
Tatar & 20.7 & 20.7 & 22.5 & 29.5 & 14.7 \\
Other & 7.5 & 5.7 & 8.2 & 6.1 & 8.8 \\
\hline
\end{tabular}

Source: R. Gallyamov, 'Politicheskie elity Rossiiskikh respublik: osobennosti transformatsii v postsovetskii period', in A. Mel'vil' (ed.), Transformatsiya Rossiiskikh regional'nykh elit v sravnitel'noi perspektive (Moscow: MONF, 1999), p. 167.

\section{Notes}

1 R. Sakwa, Russian Politics and Society (Routledge, 2nd edn, 1996), p. 31.

2 R. L. Watts, Comparing Federal Systems (Montreal and Kingston: McGill-Queen's University Press, 2nd edn, 1999), p. 6.

3 D. Kempton, 'Russian federalism: continuing myth or political salvation', Demokratizatsiya, 9:2 (Spring 2001), 229.

4 Kempton, 'Russian federalism', 202.

5 G. Smith, The Post-Soviet States (London: Arnold, 1999), p. 93.

6 According to official statistics for October 1999 to October 4, 2000, 2,500 Russian troops were killed and 7,000 wounded. See E. Pain, "Back to the USSR": new trends in Russian regional policy', Demokratizatsiya, 9:2 (Spring 2001), 187.

7 E. A. Payin, 'Ethnic separatism', in J. R. Azrael and E. A. Payin (eds) [in other cases transliterated as Pain], Conflict and Consensus in Ethno-Political and Centre-Periphery Relations in Russia (Santa Monica, California: Rand, 1998), p. 18.

8 Ibid.

9 However, Putin's attacks on the autonomy of regional elites and in particular the sovereignty claims of the ethnic republics may give nationalist movements new impetus and support (see chapter 6).

10 D. Furman, 'A disastrous love of symmetry - consolidation of the federation might only intensify separatism', Obshchaya Gazeta, 22 (June 2000), 7. Translated in the CDPSP, 52:22 (2000), 4.

11 Ibid.

12 N. Arkhangelskaya, 'The problem of separatism in Russia: elitist separatism has its price', Kommersant Daily, 29 (November 1996), p. 3. Translated in CDPSP, 48 (1996), 5.

13 E. Payin and A. Susarov, 'Line five in the mirror of demography', Rossiiskie Vesti (October 30, 1997), p. 2. CDPSP, 49:44 (1997), 10. This represents an increase of 1.42 per centage points over the last census which was compiled in 
1989. The increase is largely the result of an influx of migrants from the former republics of the USSR.

14 Ibid.

15 Ibid., 11.

16 Of the 21 republics, 7 are in the North Caucasus: (Adygeya, Chechnya, Dagestan, Ingushetiya, Kabardino-Balkariya, Karachaevo-Cherkessiya, and North Osetiya), 6 are situated in The middle reaches of the Volga River and the Urals (Bashkortostan, Chuvashiya, Marii-El, Mordoviya, Tatarstan and Udmurtiya); and 5 are located in Siberia (Buryatiya, Altai, Khakassiya, Sakha and Tuva). The remaining 3 are Kalmykiya, situated on the lower reaches of the Volga; Kareliya, on the border with Finland; and Komi, in northern European Russia. See, A. Sheehy, 'Russia's republics: a threat to its territorial integrity?', Radio Free Europe/Radio Liberty Research Report, 2:20 (May 14, 1993), 35.

17 In Dagestan there are 33 national groups, neither of which comprises a majority. Russians account for only 9.2 per cent of the total population of Dagestan.

18 Other ethnic groups which rose in size in their home republics were: Buryatiya (from 23 per cent of the total population in 1979 to 28.6 per cent in 1994); Adygeitsy in Adygeya from 21.4 to 25.2 per cent; Yakuty in Sakha (Yakutiya) from 36.9 to 39.6; Tuvintsy in Tyva from 60.5 to 67.2 per cent; Osetintsy in Ossetiya, from 50.5 to 59.3 .

19 Fedorov singles out 13 of Russia's 89 regions where the nationalities question has led to separatist demands being made by members of the regional elites; the republics of Ingushetiya, Kalmykiya, Chechnya, Dagestan, KabardinoBalkariya, Karachaevo-Cherkessiya, Altai, Tyva, Chuvashiya, Tatarstan and Bashkiriya; and Komi-Permyakiya and Aga-Buryatiya autonomous okrugs. However, the indigenous population comprises a majority in only six of these regions. See A. F. Fedorov, Rossiiskii Federalizm, p. 243.

20 One other non-ethnically based region which may eventually secede from the federation is Kaliningrad which is geographically cut off from the rest of the country nesting between the Baltic sea, bordering on Lithuania and Poland.

21 Payin, 'Ethnic separatism', p. 19.

22 This also applies to Kabardino-Balkariya and Karachaevo-Cherkessiya (see discussion below).

23 D. Treinin, The End of Eurasia: Russia on the Border Between Geopolitics and Globalisation (Washington, DC: Carnegie Endowment for Inernational Peace, 2001), pp. 253-4.

24 Ibid., p. 258.

25 Decision of the Russian Federation Constitutional Court, no. 12, July 14, 1997.

26 S. Nysten-Haarala, Development of Constitutionalism and federalism in Russia (Austria: International Institute for Applied System Analysis, 2000), p. 45.

27 In the Evreiskaya autonomous oblast, the Jewish population comprises only 4.2 per cent of the overall population and the Russian population makes up 83.2 per cent.

28 A. Paretskaya, OMRI Russian Regional Report (1997), 5.

29 A. Arbatskaya, 'Northern okrugs strengthening political influence in Tyumen', EWI Russian Regional Report, 6:45 (December 19, 2001), 4. According to Arbatskaya the okrugs have agreed to invest 15 billion dollars in the southern part of Tyumen Oblast over the period 2001-6. 
30 RFE/RL Federation Report, 3:12 (April 4, 2001).

31 EWI Russian Regional Report, 2 (January 1999).

32 On December 18, 2001 Putin signed a federal constitutional law 'On the order of adopting and establishing new federation subjects', Interfax (December 18, 2001), p. 2. As Corwin notes, according to this new law, 'if two or more federation subjects would like to combine, then the issue must first be put to a referendum for citizens within the relevant regions'. J. Corwin, 'Putin signs law on procedure for altering borders, RFE/RL Federation Report (December 19, 2001), 2.

33 S. Khemkin, 'Separatizm v Rossii - pozadi ili vperedi?', Pro et Contra, 2:2 (Spring, 1997), 18.

34 S. Parish, 'Centre continues to rail against legal separatism', OMRI Russian Regional Report, 11:3 (1996), 3.

35 Izvestiya, March 4, 1997, p. 4.

36 A. Muchnik, EWI, Russian Regional Report, 4:15 (1999), 8.

37 Vybory Glav Ispolnitel'noi Vlasti Sub'ektov Rossiiskoi Federatsii 1995-97 (Moscow: Ves' Mir, 1997), p. 10.

38 G. W. Lapidus, 'Assymetrical federalism and state breakdown in Russia', PostSoviet Affairs, 15:1 (1999), 77.

39 R. Sakwa, 'Federalism, sovereignty and democracy', in C. Ross (ed.), Regional Politics in Russia (Manchester: Manchester University Press, 2002), p. 2.

40 Smith, The Post-Soviet States, p. 185.

41 G. Smith, 'The ethno-politics of federation without federalism', in D. Lane (ed.), Russia in Transition (Harlow, Essex: Longman, 1995), p. 29.

42 A. G. Granberg, Osnovy regional'noi Ekonomiki (Moscow: Tacis, 2000), p. 303.

43 N. Grushina, 'Local authorities resort to unlawful means to raise money', OMRI Russian Regional Report, 2:10 (1997), pp. 7-8.

44 V. V. Putin, 'The kind of Russia we are building'. Annual message from the President of the Russian Federation to the Federal Assembly of the Russian Federation, Rossiiskaya gazeta (July 11, 2000), 1, 3. Translated in CDPSP, 52:28 (2000), 6 .

45 A. F. Federov, Rossiiskii Federalizm, p. 169.

46 A. Zergunin, 'Russia's regions and foreign policy', Internationale Politik, 1:3 (Autumn, 2000), 27.

47 V. Klimanov, EWI Russian Regional Report, Part 2, 4:41 (November 4, 1999), 1.

48 Ibid., 2.

49 Smith, The Post-Soviet States, p. 208.

50 Ibid., p. 209.

51 L. Smirnyagin, 'Typologies of regional conflicts in modern Russia', in Payin and Azrael, Conflict and Consensus, pp. 3-4.

52 Linz and Stepan, 'Toward consolidated democracies', p. 17.

53 D. Rustow, cited in Sorenson, Democracy and Democratisation, p. 41.

54 Smith, The Post-Soviet States.

55 G. O'Donnell, 'Delegative democracy?', University of Chicago, Working Paper, 21 (1992). Cited in A. Przeworksi, Sustainable Democracy, p. 34.

56 J. Kahn, 'A federal façade: problems in the development of Russian federalism', D.Phil. thesis (University of Oxford, 1999), p. 211.

57 Ibid., p. 213. 
58 Ibid.

59 Ibid., p. 219.

60 A. F. Fedorov, Rossiiskii Federalizm, p. 154.

61 Kahn, 'A federal façade', p. 219.

62 O. Tsvetkov, EWI, Russian Regional Report (April 5, 2001).

63 R. Gallyamov, 'Politicheskie elity Rossiiskikh respublik: osobennosti transformatsii v postsovetskii period', in A. Mel'vil' (ed.), Transformatsiya Rossiiskikh Regional'nykh Elit v Sravnitel'noi Perspektive (Moscow: MONF, 1999), p. 166.

$64 \mathrm{Kahn}$, 'A federal façade', p. 254.

65 R. Gallyamov, 'Politicheskie elity Rossiiskikh respublik', p. 167. 